\title{
Problems of infection after bone marrow transplantation
}

\author{
J GRAHAM WATSON \\ From the Royal Free Hospital, Pond Street, London NW3
}

SUMMARY Representatives of 17 bone marrow transplant (BMT) teams met to discuss the problems of infection after BMT. With experience of more than 2200 transplanted patients over the past $10 \mathrm{yr}$, the changes in the patterns of infection were surprisingly similar.

Deaths due purely to bacterial infection have greatly diminished and the major early problems today result from fungi and cytomegalovirus. The role of non-herpes group viruses has only recently received attention. With increasing numbers of survivors, late bacterial infections are assuming importance. The meeting also provided an opportunity to document the measures adopted to prevent infection during BMT and following discharge.

Infection remains one of the main problems in bone marrow transplantation (BMT). Patients are at risk of severe exogenous infection for months after a transplant and may also experience reactivation of endogenous infections. In pneumonitis, which is a major hazard especially after total body irradiation (TBI), infection is an important factor in many cases (perhaps in all), while the other main complication of transplantation, graft versus host disease (GvHD), may be precipitated or complicated by infection. Full control of infection, therefore, constitutes a vital step in the perfection of BMT procedures and a step which, theoretically at least, should be attainable.

A workshop on this topic sponsored by the Leukaemia Research Fund was held at the Royal Marsden Hospital on 25 June 1982. The intention of the conference was to bring together experience from many marrow transplant units and to review their incidence and patterns of infection and the methods of preventing or treating infection so as to provide an overview not previously available except by searching out and correlating individual reports from the published work of each centre. The questions addressed were concerned with the comparative incidence and experience of specific infections, with the regimens of decontamination, isolation, recontamination, prophylactic antibiotics, granulocyte transfusions and other measures used to prevent infection. Diagnostic procedures and treat-

Accepted for publication 6 January 1983 ments were also compared and the general question of the relation of infection and $\mathrm{G} v \mathrm{HD}$ in mouse and man was particularly emphasised. A summary of the workshop with key references has been compiled.

\section{Methods}

A questi innaire sent to each centre requested their transplant methodology and the incidence and severity of certain infections. We wished to know the numbers, nature and diagnosis of BMT recipients, the pregraft chemoradiotherapy schedules and details of the protocol used to prevent GvHD. We did not request statistics on survival, leukaemia relapse or the quality of life nor did we ask for descriptive details of $\mathrm{G} v \mathrm{HD}$. We wished to know the methods used to prevent infection immediately after BMT and after discharge from hospital; the nature, degree and duration of isolation; the prophylactic antimicrobial agents used and their route of delivery; the use of prophylactic granulocytes or a protected diet; and how long these measures continued after BMT and what new measures were adopted or instructions given on discharge home.

We sought the incidence and severity of infection with four viruses (varicella-zoster virus (VZV), herpes simplex virus (HSV), cytomegalovirus (CMV) and papovavirus), four groups of bacteria (Staph aureus, Staph epidermidis, Corynebacterium spp and anaerobes), Candida spp and Pneumocystis carinii. In addition other infections and infecting organisms were to be written into the data by teams 
who felt they had particular experience to convey. The Tables (see later) have been constructed from these data and the text contains salient points which arose in discussion.

\section{Results}

PREVENTION OF INFECTION:(Tables $1 \mathrm{a}$ and $\mathrm{b}$ )

These show the measures currently taken in 17 BMT centres to limit infection after BMT in both inpatients and outpatients. Five centres (three in the UK) do not use filtered air. Two centres (Seattle and Memorial) include a comparison of LAF with simple room isolation (as part of wider trials) and in time might be able to comment on whether stringent isolation still confers additional benefit today. It is unfortunate that both these centres include antibiotics normally regarded as important in treatment as components of their prophylactic antimicrobial regimens. No centre (except perhaps Munich) is comparing minimal isolation with more sophisticated isolation techniques while both groups receive non-absorbable antimicrobial agents.
It is not possible to compare the efficiency of different antibacterial regimens in this report. One centre, Baltimore, has used no prophylactic oral antibacterial agents (or protected diet) at the time of BMT since June 1981 so their reports of Grampositive infections (Table 5), Gram-negative infections and perhaps indirectly viral infections are of interest but include data from the time when oral prophylactic antibacterial agents were used. Future reports from Baltimore and from Seattle of their experiences with isolation plus antifungal prophylaxis only should allow an up-to-date assessment of the contribution made by prophylactic antibacterial agents in the prevention of infection and $\mathrm{G} v \mathrm{HD}$. Together with their more simple isolation studies the data being generated by these centres could have wide ranging implications for units starting BMT. Nystatin remains the most popular prophylactic antifungal agent although the early data and clinical acceptability of mepartricin make this absorbable methylated relative of amphotericin perhaps worthy of a wider trial than only Genoa. Data from the Royal Free Hospital ${ }^{1}$ suggested that

Table 1a Measures to prevent infection during $B M T$

\begin{tabular}{|c|c|c|c|c|c|}
\hline Centre & $\begin{array}{l}\text { Protected } \\
\text { environment }\end{array}$ & Prophylactic antibacterial agents & $\begin{array}{l}\text { Prophylactic antifungal } \\
\text { agents }\end{array}$ & $\begin{array}{l}\text { Prophylactic } \\
\text { granulocytes }\end{array}$ & $\begin{array}{l}\text { Protected } \\
\text { diet }\end{array}$ \\
\hline Seattle & $\begin{array}{l}\text { LAF } \\
\text { LAF } \\
\text { Room } \\
\text { Room }\end{array}$ & $\begin{array}{l}\text { Van Pol Tob po plus Tic, Tob Van iv } \\
\text { Van Pol Tob po } \\
\text { Van Tic Tob iv } \\
\text { None }\end{array}$ & $\begin{array}{l}\text { Nys } \\
\text { Nys } \\
\text { Ket } \\
\text { Nys }\end{array}$ & $\begin{array}{l}\text { No } \\
\text { No } \\
\text { No } \\
\text { No }\end{array}$ & $\begin{array}{l}\text { Sterile } \\
\text { Sterile } \\
\text { No } \\
\text { No }\end{array}$ \\
\hline Minneapolis & Room* & Cot & Nys & No & No \\
\hline Memorial & $\begin{array}{l}\text { LAF or } \\
\text { Room }\end{array}$ & $\begin{array}{l}\text { Gen Cef } \\
\text { None }\end{array}$ & $\begin{array}{l}\text { Nys } \\
\text { Nys }\end{array}$ & $\begin{array}{l}\text { No } \\
\text { No }\end{array}$ & $\begin{array}{l}\text { Sterile } \\
\text { Clean }\end{array}$ \\
\hline UCLA & Room & Van Col Cot & Nys or Ket & Not now & Clean \\
\hline Baltimore & $\begin{array}{l}\text { Room* } \\
\text { LAF }\end{array}$ & $\begin{array}{l}\text { Not now } \\
\text { "Total" }\end{array}$ & $\begin{array}{l}\text { Nys } \\
\text { Ket }\end{array}$ & $\begin{array}{l}\text { No } \\
\text { No }\end{array}$ & $\begin{array}{l}\text { No } \\
\text { Ster. GF }\end{array}$ \\
\hline Creteil & Room & Varies with antibiogram & Amph & Yes & Sterile \\
\hline Leiden-Paed & $\begin{array}{l}\text { LAF } \\
\text { LAF }\end{array}$ & $\begin{array}{l}\text { Neo Co Ceph } \\
\text { Neo Co }\end{array}$ & $\begin{array}{l}\text { Amph } \\
\text { Amph }\end{array}$ & $\begin{array}{l}\text { No } \\
\text { No }\end{array}$ & $\begin{array}{l}\text { Sterile } \\
\text { Sterile }\end{array}$ \\
\hline $\begin{array}{l}\text { Basel } \\
\text { Genoa }\end{array}$ & $\begin{array}{l}\text { LAF } \\
\text { LAF }\end{array}$ & $\begin{array}{l}\text { Gen Van Cot } \\
\text { Neo Co Cot }\end{array}$ & $\begin{array}{l}\text { Nys Amph } \\
\text { Mep }\end{array}$ & $\begin{array}{l}\text { No } \\
\text { No }\end{array}$ & $\begin{array}{l}\text { Sterile } \\
\text { Sterile }\end{array}$ \\
\hline Munich & $\begin{array}{l}\text { Room* } \\
\text { LAF }\end{array}$ & $\mathrm{Neo} \mathrm{Co} \pm \mathrm{Cot}$ & $\begin{array}{l}\text { Nys Amph } \pm \text { Mic } \\
\text { Ket }\end{array}$ & Rarely & Sterile \\
\hline $\begin{array}{l}\text { Glasgow } \\
\text { Hammersmith }\end{array}$ & $\begin{array}{l}\text { LAF } \\
\text { Room* }\end{array}$ & $\begin{array}{l}\text { Gen Van } \\
\text { Fram Co Cot }\end{array}$ & $\begin{array}{l}\text { 5FC + Nys } \\
\text { Nys Amph Ket } \\
\text { Mic }\end{array}$ & $\begin{array}{l}\text { No } \\
\text { No }\end{array}$ & $\begin{array}{l}\text { Sterile } \\
\text { Clean }\end{array}$ \\
\hline $\begin{array}{l}\text { Royal Free } \\
\text { Westminster } \\
\text { Royal Marsden } \\
\text { Gt Ormond St }\end{array}$ & $\begin{array}{l}\text { Room } \\
\text { Room } \\
\text { Room } \\
\text { Room }\end{array}$ & $\begin{array}{l}\text { Neo Co Cot } \\
\text { Neo Co } \\
\text { Neo Co or Cot } \\
\text { Neo Co or Cot }\end{array}$ & $\begin{array}{l}\text { Nys Amph Ket } \\
\text { Amph } \\
\text { Nys Amph } \\
\text { Nys }\end{array}$ & $\begin{array}{l}\text { No } \\
\text { No } \\
\text { No } \\
\text { No }\end{array}$ & $\begin{array}{l}\text { Sterile } \\
\text { Clean } \\
\text { Sterile } \\
\text { Clean }\end{array}$ \\
\hline
\end{tabular}

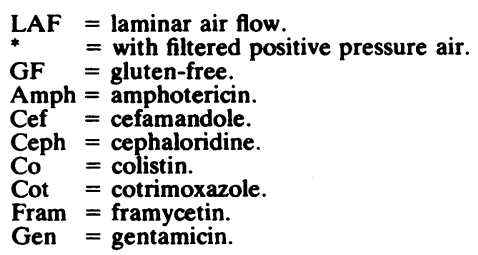


Table 1b Measures to prevent infection following discharge after BMT

\begin{tabular}{|c|c|c|c|c|}
\hline Centre & Cotrimoxazole & Penicillin & Diet & Other \\
\hline Seattle & $\begin{array}{l}\text { to } 120 \text { days } \\
\text { and during } \\
\text { treatment of } \\
\text { chronic } \mathrm{G} v \mathrm{HD}\end{array}$ & Not routinely & & $\pm \mathrm{VZ}$ transfer factor \\
\hline Minneapolis & to $1 \mathrm{yr}$ & & & Nys \\
\hline $\begin{array}{l}\text { Memoríal } \\
\text { UCLA }\end{array}$ & $\begin{array}{l}50-150 \text { days } \\
30-120 \text { days }\end{array}$ & low dose + Pneumovax & & Avoid crowds \\
\hline Baltimore & $\begin{array}{l}\text { to } 180 \text { days } \\
\text { continued if chronic } \\
\text { GvHD }\end{array}$ & low dose + Pneumovax & & $\begin{array}{l} \pm \text { Ket Tetanus and polio (salk) } \\
\text { at } 1 \mathrm{yr}\end{array}$ \\
\hline St Louis & & $\begin{array}{l}\text { to } 180 \text { days continued if } \\
\text { chronic } \mathrm{G} v \mathrm{HD}+ \\
\text { Pneumovax }\end{array}$ & & $\begin{array}{l}\text { Tetanus, polio immunisations } \\
\text { at } 180 \text { days }\end{array}$ \\
\hline $\begin{array}{l}\text { Creteil } \\
\text { Leiden-Paed } \\
\text { Basel }\end{array}$ & $\begin{array}{l}\text { to } 120 \text { days } \\
20-100 \text { days } \\
\text { for } 5 \text { days after } \\
\text { discharge }\end{array}$ & $\begin{array}{l}\text { From } 120 \text { days } \\
100 \text { days }-\mathrm{yr}^{*}+\text { Pneumovax }\end{array}$ & $\begin{array}{l}\text { Avoid some foods } \\
\text { Cooked food } \\
\text { Avoid some foods }\end{array}$ & $\begin{array}{l}\text { Neo Co Nal to } 90 \text { days } \\
\text { Avoid crowds } \\
\text { Nys Amph } 10 z \\
\text { Avoid crowds } \\
\text { Wear masks outside }\end{array}$ \\
\hline $\begin{array}{l}\text { Genoa } \\
\text { Munich } \\
\text { Glasgow }\end{array}$ & $\begin{array}{l}\text { Yes } \\
\text { to } 180 \text { days } \\
\text { Yes }\end{array}$ & & Cooked food & $\begin{array}{l}\text { Continue Neo Co Cot } \\
\text { Nys Avoid crowds } \\
\text { General advice } \gamma \text { globulin if } \\
\text { measles contact }\end{array}$ \\
\hline Hammersmith & to 100 days & & & $\begin{array}{l}\text { Amph } 10 z \\
\text { General advice }\end{array}$ \\
\hline $\begin{array}{l}\text { Royal Free } \\
\text { Westminster }\end{array}$ & $\begin{array}{l}\text { to } 180 \text { days } \\
\text { to } 150 \text { days }\end{array}$ & & Avoid some foods & $\begin{array}{l}\text { Ket }+ \text { Nys or Amph } \\
\text { Avoid close contact with } \\
\text { animals. V Ig }\end{array}$ \\
\hline $\begin{array}{l}\text { Royal Marsden } \\
\text { Gt Ormond St }\end{array}$ & $\begin{array}{l}\text { to } 150 \text { days } \\
\text { to } 100 \text { days }\end{array}$ & & $\begin{array}{l}\text { Avoid some foods } \\
\text { Avoid some foods }\end{array}$ & $\begin{array}{l}\text { Avoid pets and parties V Ig } \\
\text { Nys V Ig }\end{array}$ \\
\hline
\end{tabular}

V Ig = Varicella immunoglobulin.

$\mathrm{VZ}^{\text {= Varicella-Zoster }}$

*only in patients grafted for leukaemia

See footnote to Table 1 a for abbreviations.

ketoconazole is not adequate alone because of problems with oral absorption in irradiated patients.

Only Creteil use prophylactic granulocytes in all patients, giving $1.5 \times 10^{10}$ granulocytes $/ \mathrm{m}^{2} /$ day from day +1 to about day +18 . Their data on bacterial, fungal and viral infections are shown in the appropriate sections.

Most centres discharge their patients shortly after the granulocytes exceed $1 \times 10^{9} / 1$ and almost none relaxes the protected environment while the patient is in hospital. Patients transplanted because of immunodeficiency disease remain longer in hospital. All centres except Basel and St Louis give prophylactic cotrimoxazole to outpatients for 3-6 months and some continue for 1 yr. Only a quarter of centres give prophylaxis against pneumococcal disease at present; this is surprising since half the 65 long term ( $>5 \mathrm{yr})$ survivors at Seattle have had three or more infections after day 100 of which Strep pneumoniae and Staph aureus were predominant causes. Varicella immunoglobulin is given as routine at only three of six British centres reporting.

Several centres restrict outpatient diet in that all food must be freshly cooked. Most centres suggest avoiding crowded places. One centre insists on no pets or parties, one on no new "body contact" pets and one on wearing masks in the street. Many continue antifungal agents (usually nystatin) and in addition Creteil and Genoa continue gut decontamination for three months after discharge. Tetanus and polio immunisations are given after two months at Leiden-Paed, 6 months at St Louis; Salk polio at $1 \mathrm{yr}$ in Baltimore and the demonstration of an antibody response is required before discontinuing isolation of Westminster's children with congenital immunodeficiency and those at Leiden-Paed.

\section{SPECIFIC INFECTIONS}

\section{Fungal infections (Table 2)}

Fungal infections still cause major problems in diagnosis and treatment, despite new prophylactic antifungal agents. In Minneapolis invasive fungal disease was associated with $30 \%$ of all deaths whereas viral and bacterial infections were respectively associated with $18 \%$ and $10 \%$. In Seattle $30 \%$ of 
Table 2 Fungal infections after BMT

\begin{tabular}{|c|c|c|c|c|}
\hline \multirow[t]{2}{*}{ Centre } & \multicolumn{2}{|l|}{ Due to Candida spp } & \multirow[t]{2}{*}{ Due to Aspergillus spp } & \multirow[t]{2}{*}{ Due to others } \\
\hline & Incidence & Severe forms & & \\
\hline Seattle & $\begin{array}{l}5 \% \text { of 'bacteraemia' } \\
30 \% \text { of necropsies }\end{array}$ & & & $\begin{array}{l}\text { Various Nocardia } \\
\text { Coccidiomycosis, } \\
\text { Cryptococcus } \\
\text { Torulopsis } \\
\text { Pacillomyces }\end{array}$ \\
\hline $\begin{array}{l}\text { Minneapolis } \\
\text { Memorial }\end{array}$ & $\begin{array}{l}5 / 50 \text { patients } \\
2 / 122\end{array}$ & 2 contributed to death & $10 / 50$ & Mucor 1 \\
\hline Los Angeles & $45 / 265$ & 30 severe & $18 / 265$ & Trichosporon 1 \\
\hline Baltimore & $\begin{array}{l}\text { Incidence reduced } \\
\text { from } 20 \% \text { to } 4 \%\end{array}$ & & & $\begin{array}{l}\text { Nocardia } 1 \\
\text { Trichosporon } 1\end{array}$ \\
\hline St Louis & $8 / 63$ & & & $\begin{array}{l}\text { Torulopsis } 2 \\
\text { Cryptococcus } 1\end{array}$ \\
\hline Creteil & $4 / 34$ & 0 & 0 & \\
\hline Leiden-Paed & $1 / 31$ & 0 fatal & $0 / 31$ & \\
\hline Basel & 20 colonisations $/ 50$ & 1 severe & $1 / 50$ & \\
\hline Genoa & $4 / 56$ & 1 fatal & 140 & \\
\hline Munich & $5 / 48$ & 4 contributed to death & $1 / 48$ & \\
\hline Glasgow & $4 \mathrm{oral} / 7$ & 0 & & \\
\hline Hammersmith & $0 / 43$ & 0 & 4/5 CML & \\
\hline Royal Free & $14 / 19^{1}$ & & $4 / 66$ & Mucor 1 \\
\hline Westminster & $19 / 73$ & 1 fatal & $4 / 73$ (all fatal) & Nocardia 1 (fatal) \\
\hline $\begin{array}{l}\text { Marsden } \\
\text { Gt Ormond St }\end{array}$ & $\begin{array}{l}18 / 66 \\
1 / 23\end{array}$ & $\begin{array}{l}3 \text { contributed to death } \\
\text { Fatal }\end{array}$ & $1 / 23$ & \\
\hline
\end{tabular}

necropsies showed invasive candidiasis. In this necropsy series the incidence of fungal infection after BMT for aplasia $(46 \%)$ was twice that after BMT for acute leukaemia (20\%), almost certainly due to the more prolonged neutropenia of aplasia. Their patients with severe neutropenia $\left(<0 \cdot 1 \times 10^{\%} / 1\right)$ lasting up to 20,40 and 60 days have incidences of $21 \%, 41 \%$ and $57 \%$ respectively of invasive fungal disease.

Aspergillus spp occupied considerable discussion. Minneapolis reported 13 episodes in 10 patients (out of 50) of whom nine died. The one survivor had only a thigh infection; the other nine had pulmonary aspergillosis with central nervous system dissemination in five. Only one pulmonary aspergillosis was diagnosed before death (investigation in all included lung biopsy) and seven of the ten were receiving empirical amphotericin $B$. These infections had no seasonal incidence, occurred any time after BMT and five patients had other infections at the time. Eight of ten had been receiving long term broad spectrum antibiotics. Although Westminster wash out radiologically abnormal sinuses before BMT, all four aspergillosis infections (all fatal) in their experience originated there.

The importance of filtering air to remove Aspergillus spp was shown by Peterson who described how placing HEPA recirculating filters in each room reduced the incidence of invasive aspergillosis from $12 / 65(18 \%)$ to $3 / 66(5 \%)$ and additional nasopharyngeal colonisation from $5 / 65$ to $2 / 66$ patients, without any change in the incidence of these problems in the rest of the hospital. Adequate filtration to exclude the smaller spores of Aspergillus fumigatus was essential in preventing disease.

Two studies of prophylactic ketoconazole versus oral nystatin and amphotericin were reported. Both Prentice ${ }^{1}$ and Gluckman independently described considerable reduction in fungal infections in the patients who received ketoconazole but controls were historical in the Gluckman study and the dose of nystatin $\left(1.2 \times 10^{6}\right.$ units/day) considered inadequate by some in the other. The optimal prophylactic regimen is not yet agreed. Prentice described considerable reduction in the absorption of ketoconazole after day 21 associated with abnormalities of gastrointestinal function. ${ }^{1}$ Mepartricin, an orally absorbed methyl ester of an amphotericinlike heptane is without renal toxicity as described by Bacigalupo (Genoa) ${ }^{2}$ and appears of great interest although his incidence of positive candida cultures when using either prophylactic mepartricin or ketoconazole was similar though much less than in the patients who received nystatin or miconazole.

Even adequate treatment may not be sufficient unless also commenced at an early stage. Because it is unusual to culture Aspergillus sp in the absence of invasive disease, it was strongly recommended that any patient with a positive culture for aspergilli should receive a total of $2 \mathrm{~g}$ amphotericin $\mathrm{B}$; and if treating possible clinical disease the early institution of treatment is of the greatest importance. A suggested schedule is $1 \mathrm{mg}$ amphotericin test dose 
intravenously followed one hour later by $20 \mathrm{mg}$ infused over $24 \mathrm{~h}$ and then $50 \mathrm{mg}$ during each $24 \mathrm{~h}$ to a total of $2 \mathrm{~g}$. Some felt 5-fluorocytosine and rifampicin were helpful, and that radiological sinusitis with a pulmonary infiltrate should be regarded as due to Aspergillus sp until proved otherwise.

\section{Cytomegalovirus infections and pneumonitis (Table 3)}

Cytomegalovirus (CMV) gave rise to much discussion because of the prevalence of fatal CMV pneumonitis, the difficulty of aetiological diagnosis in pneumonitis, the lack of effective treatment and the suspicion that most CMV infection in seronegative BMT patients is iatrogenic.

Between $10 \%$ and $50 \%$ of patients develop CMV infection after BMT. Fifty-nine percent of USA patients with CMV developed CMV pneumonitis compared to $23 \%$ of European patients, the proportion of such pneumonitis proving fatal being $60 \%$ on both sides of the Atlantic. Factors which increase the incidence of CMV pneumonitis and CMV infection include being a caucasian; GvHD grade II or greater; age $>12 \mathrm{yr}$; lung radiation greater than 6 Gy; preceding recipient CMV seropositivity; recipient seronegativity with donor seropositivity (not in Seattle); the giving of granulocytes and degrees of recipient/donor HLA matching which are less than fully compatible. ${ }^{3}$

Pneumonitis was twice as common after BMT for acute leukaemia as after aplastic anaemia ( $p<$ 0.005 ) but even with transplants for aplasia the incidence varies with the conditioning regimen. Assessed 15 weeks after BMT for aplasia, cyclophosphamide, PAPACY and TBI preconditioning regimens were associated with incidences of pneumonitis of $8 \%, 30 \%$, and $70 \%$ respectively. $^{3}$ The lesser incidence of interstitial pneumonitis after syngeneic BMT is due mainly to an absence of CMV pneumonitis. True idiopathic pneumonitis seems as common after syngeneic BMT as after allogeneic BMT. Barrett and Depledge ${ }^{4}$ have shown a clear relation between total lung radiation dose and the incidence of lung complications after BMT in man and also how a dose rate of $0 \cdot 1 \mathrm{~Gy} / \mathrm{min}$ or greater seriously and increasingly impairs gas transfer in mice. A recent International Registry report ${ }^{5}$ concerning 176 patients transplanted for acute leukaemia identified three of 30 prognostic factors significantly $(p<0.005)$ associated a low risk of pneumonitis-a radiation dose rate less than 0.057 $\mathrm{Gy} / \mathrm{min}$, cyclosporin A rather than methotrexate as prophylaxis against $\mathrm{G} v \mathrm{HD}$ and female donor marrow into a female recipient.

There was much interest in the relevance of
Table 3 Cytomegalovirus infections after BMT

\begin{tabular}{lcl}
\hline Centre & Incidence & Severe forms \\
\hline Seattle & $50-60 \%$ & $\begin{array}{l}\text { fatal pneumonitis in } 15- \\
20 \% \text { of leukaemias, }<5 \% \\
\text { of aplastics: also } \\
\text { leukopenia, hepatitis and } \\
\text { possibly graft rejection in } \\
\text { aplastics }\end{array}$ \\
Minneapolis & $13 / 50$ (patients) & 10 pneumonitis \\
Memorial & $16 / 122$ & 55 \\
Los Angeles & $80 / 256$ & 51 pneumonitis. $31 \%$ fatal \\
Baltimore & $89 / 200$ & 5 pneumonitis. $60 \%$ fatal \\
St Louis & $31 / 63$ & 1 encephalitis; 1 fatal \\
Creteil & $7 / 34$ & pneumonitis \\
Leiden-Paed & $4 / 31$ & 4 fatal pneumonitis \\
Basel & $4 / 50$ & 2 fatal pneumonitis \\
Genoa & $8 / 56$ & 1 fatal pneumonitis \\
Munich & $2 / 48$ & 2 fatal pneumonitis \\
Glasgow & $0 / 7$ & 6 pneumonitis $(4$ fatal) \\
Hammersmith & $6 / 43$ & 1 encephalitis, \\
Royal Free & $16 / 47$ & 1 pneumonitis, \\
Westminister & $22 / 73$ & 2 hepatitis \\
& & 6 contributed to death \\
Royal Marsden & $23 / 86$ & Fatal \\
\hline Gt Ormond St & $1 / 23$ &
\end{tabular}

donor/recipient CMV serology. Patients who receive prophylactic granulocytes have an increased risk of CMV which is dependent upon whether the granulocyte donors are seropositive or seronegative $(p=0.005)$. A smaller difference is seen between similar groups of patients who receive therapeutic granulocytes $p=0.027$ ). Extending their 1980 report $^{6}$ Young reported that when only CMVnegative recipients were studied, $16 / 46(35 \%)$ who received prophylactic granulocytes from only CMV-negative donors developed CMV compared to $21 / 28(75 \%)$ who received prophylactic granulocytes from only CMV-positive donors. $(p<0.01)$. The presumption is that platelets and blood transfusions contribute a significant proportion of the remaining infections. Should granulocytes be required, Seattle use single family member donors for individual patients. Creteil (Jean Vernant) were the only centre using a full prophylactic granulocyte regimen-an average of $1.52 \times 10^{10}$ granulocytes $\mathrm{m}^{2} /$ day from days +1 to +18 after BMT. Of 34 such patients, seven experienced CMV infection-five benign hepatitis, one encephalitis (resolved) and one fatal interstitial pneumonia. Their overall incidence of interstitial pneumonia in remission BMT patients was 11 of 49 (2 fatal), a greater incidence of interstitial pneumonia occurring in those who did not receive granulocytes. More data are required to explain their low incidence of CMV in the presence of such quantities of unscreened granulocytes.

No useful therapy for CMV has yet emerged in that bromovinyl deoxyuridine (BVDU), adenine arabinoside, interferon from various sources and 
acycloguanosine in various combinations have proved ineffective and sometimes toxic (eg adenine arabinoside and interferon) and CMV infection has developed during long-term prophylactic acyclovir $\left(10 \mathrm{mg} / \mathrm{kg} /\right.$ day). Winston (UCLA) presented data ${ }^{7}$ from 48 patients using $10 \mathrm{ml} / \mathrm{kg}$ of CMV hyperimmune plasma (titre 1/256) before and after BMT and showed a substantial reduction only in those patients who did not receive granulocytes. Meyers (Seattle) $^{8}$ also reported a reduction in CMV infections in a 50 patient study of passive protection with exogenous CMV antibody but again the benefit appeared to be confined to those who did not receive exogenous granulocytes. It would seem that these infusions coupled with careful selection of donors when possible or applicable are the only measures to prevent CMV disease at the moment.

Peterson reported experience with open lung biopsy (OLB). In these data $5 / 9$ patients with pneumonitis diagnosed as "idiopathic" by transbronchial needle biopsy were shown to be due to CMV on OLB. OLB is associated with no mortality and negligible morbidity on the West Coast of the United States. It satisfies the two major requirements, adequate specimens and good haemostasis and new aetiological agents might be found-for example, four recent chlamydial pneumonias in Seattle-where the workers are sufficiently confident that if no pathogens are identified on OLB the diagnosis must be radiation pneumonitis, dexamethasone $16 \mathrm{mg} /$ day is given and not antimicrobial agents. Saral (Baltimore) disagreed, stating that in
Baltimore pneumonitis of unknown cause is treated with Septrin and erythromycin and occasionally four days of steroids without OLB.

Recent work on the relation between the stem cell, CMV and the maturing donor marrow was described by Saral. Stem cells undifferentiated while propagating in culture, when infected with murine CMV, do not allow CMV replication and no virus, no viral RNA and no viral antigens can be identified until stem cell differentiation occurs. However viral DNA is present. The viral DNA genome is therefore latent and activation awaits the differentiation of the infected cell. Saral also described cellular methods of assessing the prognosis in CMV infection. Cytotoxic T cell responses and NK cells were preserved in post BMT patients with non-fatal CMV whereas they were very low in patients whose CMV ultimately proved fatal. ${ }^{9} \beta$-interferon could restore these absent responses in approximately half the in vitro tests.

Varicella-zoster and herpes simplex viruses (Table 4) It was striking how uniform the experience of centres was in the incidence of $\mathrm{VZ}$ infections, approximately $40 \%$ of survivors of BMT developing zoster. Between $20 \%$ and $40 \%$ of these develop disseminated disease and there was no evidence that the routine prophylactic use in three centres of varicella immunoglobulin (Table 1b) during the first three months after BMT reduced their incidence of zoster. A mortality rate of about $5 \%$ of cases was quoted, predominantly due to varicella pneumonia.

Table 4 Varicella-zoster and herpes simplex virus infections after BMT

\begin{tabular}{|c|c|c|c|c|}
\hline \multirow[t]{2}{*}{ Centre } & \multicolumn{2}{|l|}{ Varicella-zoster } & \multicolumn{2}{|l|}{ Herpes simplex } \\
\hline & Incidence & Severe forms & Incidence & Severe forms \\
\hline Seattle & $\begin{array}{l}215 / 1000+\text { cumulative } \\
40 \% \text { usually first } \\
5 \text { months }\end{array}$ & $\begin{array}{l}5 \% \text { fatal } 1 / 3 \text { disseminate } \\
1 / 6 \text { varicella type onset }\end{array}$ & $80 \%$ of antibody + & $\begin{array}{l}20+\text { fatal pneumonias } \\
\text { some severe mucositis, } \\
\text { oesophagitis }\end{array}$ \\
\hline Minneapolis & 4/50 (patients) & 0 & $11 / 50$ & \\
\hline Memorial & $26 / 122$ & & $35 / 122$ & 1 \\
\hline Los Angeles & $20 / 265$ & 5 generalised 1 fatal & $200 / 265$ & 15 \\
\hline Baltimore & $40 \%$, median at 3 months & $4 \%$ fatal & $\begin{array}{l}113 / 27072 \% \text { of } \\
\text { antibody }+\end{array}$ & $\begin{array}{l}2 \text { encephalitis } \\
6 \text { pneumonitis }\end{array}$ \\
\hline $\begin{array}{l}\text { St Louis } \\
\text { Creteil }\end{array}$ & $14 / 63$ & & $27 / 63$ & \\
\hline $\begin{array}{l}\text { Creteil } \\
\text { Leiden-Paed }\end{array}$ & $\begin{array}{l}7 / 34 \\
5 / 31\end{array}$ & $\begin{array}{l}0 \\
1 \text { generalised }\end{array}$ & $\begin{array}{l}8 / 34 \\
3 / 31^{*}\end{array}$ & $\begin{array}{l}0 \\
0\end{array}$ \\
\hline Basel & $6 / 50$ & & $19 / 50^{*}$ & 2 encephalitis \\
\hline $\begin{array}{l}\text { Genoa } \\
\text { Munich }\end{array}$ & $\begin{array}{l}3 / 56 \\
7 / 48\end{array}$ & & $\begin{array}{l}4 / 56 \\
4 / 48\end{array}$ & \\
\hline $\begin{array}{l}\text { Munich } \\
\text { Glasgow }\end{array}$ & $\begin{array}{l}7 / 48 \\
0 / 7\end{array}$ & 0 & $\begin{array}{l}4 / 48 \\
1 / 7\end{array}$ & 1 fatal \\
\hline Hammersmith & $12 / 43$ & 1 generalised & $13 / 43^{*}$ & \\
\hline $\begin{array}{l}\text { Royal Free } \\
\text { Westminster }\end{array}$ & $\begin{array}{r}5 / 37 \\
11 / 73\end{array}$ & 1 fatal pneumonia & $\begin{array}{l}17 / 37^{11} \\
13 / 73^{11}\end{array}$ & \\
\hline Royal Marsden & $18 / 66$ & 2 generalised & $22 / 66^{*}$ & 1 encephalitis \\
\hline Gt Ormond St & $2 / 23$ & 0 & $0 / 23$ & \\
\hline
\end{tabular}

*Made specific comment on recurrence. 
It is likely that the early use of acyclovir will reduce this.

Discussion of herpes simplex (HSV) mainly centred around the use of acycloguanosine (ACG). Intravenous $\left(250 \mathrm{mg} / \mathrm{m}^{2}\right.$ tds) ${ }^{10}$ and to a lesser extent oral $(5 \mathrm{mg} / \mathrm{kg} \mathrm{bd})^{11}$ prophylaxis were effective in preventing HSV lesions developing and intravenous therapy led to rapid resolution of active lesions. ${ }^{12}$ The place of oral therapy is still to be resolved but the problems of rapid recurrence of lesions after treatment is stopped would probably remain. Resistance to ACG by HSV was reported but all strains which have been tested lacked thymidine kinase ( $3 / 3$ in Seattle, 6/6 in Baltimore and St Louis, Paris) and consequently had thrived despite ACG. ${ }^{13}$ Several centres reported recurrent HSV after stopping treatment but almost all patients responded well to a second course. Meyers (Seattle) described a brief syndrome, occurring in six patients, five of whom had received high ACG doses, which was characterised by tremor, disorientation and mood changes but generally without focal signs. Although attributed by Meyers to ACG, Saral and Gluckman had seen this in the absence of ACG and attributed it to a late effect of the preconditioning. Not one of the six encephalitides in Table 4 was proven by biopsy. No-one suggested that strange neurological syndromes may be due to cyclosporin A which has been shown to produce considerably different toxic effects in younger age groups. ${ }^{14}$ Concern was expressed by some that ACG might affect bone marrow recovery despite the difficulty of differentiating ACG effects from those of the virus.

No data were presented or cited to implicate ACG in slow marrow recovery. Workers reported that $30 \mathrm{mg} / \mathrm{kg} / \mathrm{dose}$ of ACG if given with one litre of fluid per gram of drug caused no renal toxicity.

\section{Other viruses}

The Baltimore experience with viral gastroenteritis after BMT was recently reported. ${ }^{15}$ This showed $40 \%$ of BMT recipients became infected with one or more viruses during their initial admission and drew particular attention to adenovirus, rotavirus and Coxsackie virus as pathogens. Seventeen of 31 patients (13 of 22 viral excretors) with enteric pathogens in their stools died compared to 6 of 47 without enteric pathogens.

Other centres reported their commoner isolates. Papovavirus, usually BK strain, was found in the urine of between $30 \%$ and $80 \%$ of BMT recipients (Memorial, Baltimore, Westminster), with a possible association with mild hepatotoxicity. ${ }^{16}$ No definite evidence of neurotoxicity has emerged, even in those who excreted JC virus. Adenovirus caused at least 70 severe infections with a mortality rate of about $15 \%$ reported from several centres. Serotypes 2,5 and 11 predominated and infection was manifest most usually as a respiratory disease which rapidly led to severe gut and renal damage. Coxsackie $A$ 1, 2, 5 have predominantly been shed without disease, although both Coxsackie virusinfected Baltimore patients died. One patient died of influenza in Basel. Epstein-Barr virus remains an area ripe for exploration. Although Westminster reported 14 seroconversions after BMT, there was only a possible association with hepatitis and GvHD.

\section{Infections with Gram-positive cocci (Table 5)}

Staph aureus infections were not considered a major problem. With the exception of Seattle and Baltimore, there were 45 infections reported of which seven (16\%) were fatal. Saral (Baltimore) felt Staph aureus was a major cause of infection in chronic GvHD and Meyers described Staph aureus as a frequent cause of late infection ( $>100$ days after BMT).

In contradistinction, Staph epidermidis infections are currently the most common cause of bacteraemia in Seattle and certain other centres, and although not often fatal (8 of 103 on whom full data were available) protracted illness, extensive soft tissue infections, endocarditis, pneumonia and infected emboli were described. Frequent resistance to all antimicrobials except vancomycin was found in some centres and this antibiotic is included in the combination of antimicrobials used at the onset of pyrexia in Seattle despite concern about the toxicity of the combination of cyclosporin $A$ and vancomycin. Double lumen "Hickman" catheters allowing separate channels for giving and withdrawal did not reduce the incidence of Staph epidermidis septicaemia. However, Westminster reported that careful attention to sterile technique plus keeping the end of the "Hickman" line in a sterile finger cot or the catheter/giving set junction in a sterile plastic bag had eliminated their problem with Staph epidermidis septicaemia, not now seen for 10 months. ${ }^{17}$ There was general agreement that indwelling intravenous lines should be removed in the event of septicaemia with the possible exception of Staph epidermidis.

Pneumococcal infections remain a problem, particularly later than $\mathbf{1 0 0}$ days after BMT. Resistance to Septrin, delayed and poor responses to Pneumovax immunisation (particularly the 6A antigen-the most common serotype in Los Angeles) and impaired splenic function were all cited as reasons, but no-one commented on a change in their local incidence once prophylactic penicillin was given. 
Table 5 Gram-positive bacterial infections after BMT

\begin{tabular}{|c|c|c|c|c|c|}
\hline Centre & Staph aureus & Staph epidermidis & Strep pneumoniae & Corynebacteria & Other Gram-positive \\
\hline Seattle & $\begin{array}{l}5-10 \% \text { of } \\
\text { bacteraemias }\end{array}$ & $\begin{array}{l}33 \% \text { of } \\
\text { bacteraemias }\end{array}$ & $\begin{array}{l}\text { Frequent late } \\
\text { infections }\end{array}$ & $\begin{array}{l}40-50 / 1000+ \\
\text { now rare }\end{array}$ & \\
\hline Minneapolis & 2/50 (patients) & $12 / 50$ & & & $10 / 50$ \\
\hline Memorial & $4 / 122$ & $17 / 122$ & & $1 / 122$ & $2 / 122$ \\
\hline Los Angeles & $12 / 265$ septicaemias & $65 / 265$ & $\begin{array}{l}\text { Frequent late } \\
\text { infections }\end{array}$ & $15 / 265$ & \\
\hline Baltimore & More frequent now & $\begin{array}{l}\text { Major cause of } \\
\text { infection }\end{array}$ & 4 fatal & declining & \\
\hline St Louis & $6 / 63$ & $32 / 63$ & 3 & $4 / 63$ & $15 / 63$ \\
\hline Creteil & $0 / 34$ & $0 / 34$ & 1 fatal (late) & $0 / 34$ & \\
\hline Leiden-Paed & $3 / 31$ & $3 / 31$ & & & $3 / 31$ \\
\hline Basel & $0 / 50$ & $3 / 50$ & & $0 / 50$ & \\
\hline Genoa & $7 / 56$ & $14 / 56$ & & $8 / 56$ & $2 / 56$ \\
\hline Munich & $2 / 48$ & $1 / 48$ & & $0 / 48$ & $3 / 48$ (1 fatal) \\
\hline Glasgow & $0 / 7$ & $0 / 7$ & & & \\
\hline Hammersmith & $2 / 41$ & $5 / 43$ & & $1 / 43$ & \\
\hline Royal Free & $0 / 20$ & $60 \%$ of bacteraemias & & & \\
\hline Westminster & $2 / 73$ & $19 / 73$ & $5 / 73$ & & \\
\hline Marsden & $5 / 66$ & $6 / 66$ & 2 fatal & $2 / 66$ & \\
\hline Gt Ormond St & $0 / 23$ & $0 / 23$ & & $0 / 23$ & \\
\hline
\end{tabular}

\section{Anaerobic infections}

A small proportion of bacteraemias $(<5 \%)$ were due to anaerobic organisms, mainly Clostridium difficile and Bacteroides spp, but these did not constitute a problem and many centres had identified no anaerobic infections.

\section{Gram-negative infections}

Meyers (Seattle) reported that from 1969-73 Gram-negative organisms caused $71 \%$ of infections, from 1974-1976 50\%, and from 1976-80 21\% of infections. The data from all centres mirrored this decline and the speciation of isolates in most centres was similar with E coli, Pseudomonas spp and Klebsiella spp accounting for almost all Gram-negative septicaemias. The vast majority were associated with neutropenia and although overall about one in five proved fatal, the influences of coexisting $\mathrm{G} v \mathrm{HD}$, or in aplasia, graft failure suggest that death due to "pure" Gram-negative septicaemia is a relatively unusual event.

\section{OTHER INFECTIONS}

\section{Toxoplasmosis}

St Louis, reported three cases, all about six months after BMT. Two presented with early CNS involvement, rapidly progressed and died. Seattle had seen six cases (all fatal) with, variably, pneumonia, myocarditis and encephalitis.

\section{Tuberculosis}

Basel reported two cases both treated successfully and the Royal Free, one fatal case. Fatal disseminated BCG disease in a six-month infant with SCID, who had been immunised at birth with rapid and apparently normal healing of the immunisation site was reported from Westminster.

\section{The role of infection in precipitating $\mathrm{G} v \mathrm{HD}$}

The experimental relation between infection and GvHD was explored by two speakers. Heidt described earlier mouse work where the germ-free state conferred great protection against death from delayed GvHD but that continuation of the germfree state was only necessary for $\mathbf{4 0}$ days after transplantation. Earlier conventionalisation resulted in fatal GvHD. ${ }^{18} 19$ No single organism, antigen or endotoxin has been identified which will precipitate this reaction but Gram-negative bacteria seem to play an important role. The degree of protection from $\mathrm{G} v \mathrm{HD}$ by the decontaminated state seems to be related to the number of immune competent cells present in the graft. ${ }^{20}$

Experiments with (C57BLxCBA) F1 hybrids have shown that after transplantation with CBA bone marrow and spleen cells, the damage to subcutaneous implanted fetal F1 gut in a conventional recipient by $\mathrm{G} v \mathrm{HD}$ is twice as great as in F1 fetal gut implants carried by decontaminated chimeras, $N$ despite also not being in contact with alimentary flora. CBA fetal gut implants developed substantial damage when present in conventional chimeras, but not when present in decontaminated chimeras. The derived hypothesis is that gut microfloral antigens gained access via minor GvHD lesions, crossreacted with host tissue antigens and induced a secondary response in the transplanted cells which then reacted with the recipient tissue. ${ }^{21}$ Germ-free monkeys survive BMT better than conventional monkeys because of a reduction in GvHD and even monkeys who are fully MLA matched are also relatively 
protected.

Similar results were reported by Truitt who used AKR mice with end-stage leukaemia to show that decontamination should commence a minimum of 10 days before BMT in order to have maximum reduction in post-BMT mortality. Maximum benefit was obtained only when both decontamination and isolation in a protective environment were used. Decontamination and isolation per se did not eliminate the $\mathrm{G} v \mathrm{HD}$ reaction in immunosuppressed leukaemic AKR mice; however, much of the mortality associated with GvHD was eliminated. The degree of G $v \mathrm{HD}$ remaining was dependent on the compatibility of the donor and host as well as the dose of post-thymic lymphocytes transplanted. Bacteria-free "leukaemia-cured" AKR chimeras could be returned to a conventional microbial environment without significant increase in mortality but the timing of this reconventionalisation was crucial.

Vossen $^{22}$ reported data from Leiden concerning high dose total (Neo Co Ceph) and low dose selective (Neo $\mathrm{Co}$ ) prophylactic oral antimicrobial decontamination and the incidence of acute GvHD in children transplanted for aplasia (Table 6). Suppressed stools were those from which Gram-negative bacteria or fungi could not be isolated. Children with suppressed stools had less GvHD ( $p<0.5>$ $0 \cdot 1$ ) but "total" decontamination resulted in a much lower incidence of GvHD though the proportion of consistently suppressed stools was similar. There was no difference in the incidence of infections. Early onset acute G $v \mathrm{HD}$ is due to the cytotoxicity of transplanted mature lymphocytes whereas late onset ( $>3$ weeks after BMT) acute GvHD is caused by T lymphocytes which have matured out of the graft under the influences prevailing at that time. Severe early onset $\mathrm{G} v \mathrm{HD}$ was seen only in children with hereditary forms of aplasia, but exclusion of these five children shows late onset GvHD in 3 of 12 suppressed.

The most striking "effect" on late onset acute $\mathrm{G} v \mathrm{HD}$ was seen in the totally suppressed group: no $\mathrm{G} v \mathrm{HD}$ out of five non-hereditary aplasias. The same "effect" was not seen in the selectively suppressed group: three GvHD out of seven nonhereditary aplasias. It was suggested that gut bac-

Table 6 Stool flora and the incidence of GvHD

\begin{tabular}{llll}
\hline $\begin{array}{l}\text { Nature of } \\
\text { decontamination }\end{array}$ & $\begin{array}{l}\text { Consistent stool } \\
\text { microbiological } \\
\text { findings }\end{array}$ & Acute GvHD & $\begin{array}{l}\text { Acute } G v H D \\
\text { of late onset }\end{array}$ \\
\hline Total & Suppressed 6 & 0 & 0 \\
& Not suppressed 4 & 3 & 2 \\
Selective & Suppressed 8 & 4 & 3 \\
& Not suppressed 3 & 3 & 1 \\
\hline
\end{tabular}

teria or their products together may contribute to GvHD. Stool endotoxin concentrations suggested an association with the development of $\mathrm{G} v \mathrm{HD}$ but the inclusion of oral colistin, an endotoxin-binding agent, in the regimens made interpretation difficult. The low rate of chronic $\mathrm{GvHD}(2$ of 25 aplastics; 0 of 8 acute leukaemia patients) may reflect the degree of microbial suppression achieved by Vossen et al. ${ }^{22}$

Active and passive recontamination were briefly discussed. Various centres recounted anecdotes of acute $\mathrm{G} v \mathrm{HD}$ developing shortly after either active recontamination, withdrawal of decontamination or discharge home yet while continuing oral Septrin, but no centre has any study of the precipitation of $\mathrm{GvHD}$ in relation to the changing stool microbiology after discharge from hospital.

\section{Conclusion}

It was evident that very different degrees of importance are attached in different places to the role of infection in causing GvHD. Experimental data would seem to indicate the need for relatively complete and prolonged bacterial decontamination before and after transplant (perhaps as much as $\mathbf{1 2}$ days before and 60-80 days after) but the practical difficulties of doing so (which would among other things reduce the number of transplants done) and the difficulties of assessing the benefits have largely inhibited attempts at comparative trials. With an ever-expanding scope for marrow-transplants-for example, for thalassaemia and for the use of nonmatched donors-this problem will remain without easy solution. The workshop was an invaluable opportunity to compare detailed results and the information exchanged will undoubtedly lead to improved practices in many circumstances, but no obvious pathway to clarify the relation of infection and $\mathrm{G} v \mathrm{HD}$ in man was proposed.

I am grateful to the Leukaemia Research Fund for sponsoring this workshop and Prof HEM Kay for advice. Institutions contributing patient data for this report were:

Academisch Zieckenhuis, Leiden (J Vossen).

Fred Hutchinson Cancer Research Center, Seattle

(J Meyers).

Hammersmith Hospital, London (J Goldman).

Hospital Henri Mondor, Creteil (J Vernaut).

Hospital St Louis, Paris (E Gluckman).

Johns Hopkins University School of Medicine, Baltimore (R Saral).

Kantonsspital, Basel (B Osterwalder).

Ludwig-Maximilians-Universität, Munich 
Ospedali Civili di Genova (A Bacigalupo).

Royal Free Hospital, London (G Prentice).

Royal Hospital for Sick Children, Glasgow (M Willoughby).

Royal Marsden Hospital, London (R Powles).

The Hospital for Sick Children, London ( $R$

Levinsky).

Sloan Kettering Cancer Center (R O' Reilly).

UCLA School of Medicine, Los Angeles (L Young).

University of Minnesota (P Peterson).

Westminster Children's Hospital, London ( $T$ Rogers).

\section{References}

' Hann IM, Prentice HG, Corringham Ret al. Ketoconazole versus amphotericin B plus nystatin for fungal prophylaxis in severely immunocompromised patients. Lancet 1982;i:826-9.

${ }^{2}$ Van Lint MT, Bacigalupo A, Frassoni F et al Ketoconazole versus mepartricin for the prevention of candida infections in the immunocompromised host. Exp Hematol 1982;10 suppl 10:6-7.

${ }^{3}$ Meyers JD, Flournoy N, Thomas ED. Non-bacterial pneumonia after allogeneic marrow transplantation-review of ten years experience. Rev Infect Dis 1983; (in press).

${ }^{4}$ Barrett A, Depledge MH. Total body irradiation: some factors affecting outcome. Exp Hematol 1982;10, suppl 10:56-63.

${ }^{5}$ Bortin MM, Kay HEM, Gale RP, Rimm AA. Factors associated with interstitial pneumonitis following bone marrow transplantation for acute leukaemia. Lancet 1982;i:437-9.

- Winston DJ, Winston G, Ho MD, et al. Cytomegalovirus infections associated with leukocyte transfusions. Ann Intern Med 1980;93:671-5.

' Winston DJ, Pollard RB, Ho WG, et al. Cytomegalovirus immune plasma in bone marrow transplant recipients. Ann Intern Med 1982;97:11-18.

${ }^{8}$ Meyers JD, Leszczynski J, Zia JA, Levin MJ, Wright GG, Thomas ED. Clin Res 1982;30:374A (abstract).

9uinnan GV, Kirmani N, Rook AH, et al. Cytotoxic T cells in cytomegalovirus infection. N Engl J Med 1982;307:7-13.

${ }^{10}$ Saral R, Burns WH, Laskin OL, Santos GW, Leitman PS. Acyclovir prophylaxis of herpes-simplex-virus infections. $N$ Engl J Med 1981;305:63-7.
"Hann IM, Prentice HG, Blacklock HA, et al. Acyclovir prophylaxis of herpes virus infections in severely immunocompromised patients: A randomised double blind trial. $\mathrm{Br}$ Med J 1983; (in press).

${ }^{12}$ Selby PJ, Powles RL, Jameson B et al. Parenteral acyclovir therapy for herpes virus infections in man. Lancet 1979;ii:1267-70.

${ }^{13}$ Burns WH, Saral R, Santos GW, et al. Isolation and characterisation of resistant herpes simplex virus after acyclovir therapy. Lancet 1982;i:421-3.

14 Joss DV, Barrett AJ, Kendra JR, Lucas CF, Desai S. Hyper- C tension and convulsions in children receiving cyclosporin $\mathrm{A}$. Lancet 1982;i:906.

is Yolken RH, Bishop CA, Townsend TR, et al. Infectious gastroenteritis in bone marrow recipients. $N$ Engl J Med 1982;306:1009-12.

${ }^{16}$ O'Reilly R, Lee FK, Grossbard E et al. Papovavirus excretion following marrow transplantation: incidence and association with hepatic dysfunction. Transplant Proc 1981;13:262-6.

17 Watson AJ. Staph epidermidis infections can be prevented. Nursing Times 1983; (in press).

18 Van Bekkum DW, Roodenburg J, Heidt PJ, van der Waaij D. Mitigation of secondary disease of allogeneic mouse radiation chimeras by modification of the intestinal microflora. $J$ Natl Cancer Inst 1974;52:401-4.

19 Van Bekkum DW. Bone marrow transplantation. Transplant Proc 1977;9:147-54.

${ }^{20}$ Heidt PJ, Wagemaker G, Knaan-Shanzer S, van Bekkum DW. $\vec{\theta}$ Two distinct types of late onset graft-versus-host disease after bone marrow transplantation in lethally irradiated mice. Transplantation 1981;32:263-4.

${ }^{21}$ Van Bekkum DW, Knaan S. Role of bacterial microflora in development of intestinal lesions from graft-versus-host reaction. J Natl Cancer Inst 1977;58:787-90.

22 Vossen JM, Heidt PJ, Guiot HFL et al. Prevention of acute graft-versus-host disease in clinical bone marrow transplantation: complete versus selective intestinal decontamination. In: Sasaki S, ed. Recent advances in germ free research Tokai: Tokai University Press, 1981:573-7.

Requests for reprints to: Dr J Graham Watson, Department of Paediatrics, Royal Free Hospital, Pond Street, London NW3, England. 